\title{
STUDENTS' ATTITUDE TOWARDS LEARNING METHODS FOR SELF-SUFFICIENCY DEVELOPMENT IN HIGHER EDUCATION
}

\author{
Ausra Rutkiene \\ Ilona Tandzegolskiene \\ Vytautas Magnus University, Lithuania
}

\begin{abstract}
The diversity of teaching methods and the change in the teaching paradigm which emphasises a student-directed teaching and holistic approach altered the understanding of the role of the teaching/learning methods as mediators between lecturers and students. A method is seen not only as a means to master the material of the discipline or to enhance language skills, but also as a complex tool which allows the student to adapt to teaching material, to socialize in a group, to know and evaluate oneself and to develop argumentative and critical thinking. The results show that the most common teaching methods (lecturing, explanation, narration, demonstration) are not active. Active, application and practice oriented teaching methods are relatively rare. With respect to the self-sufficient learning it turned out that students mostly see the value in the possibility to plan their study process, to observe, adjust and evaluate their learning results and process.
\end{abstract}

Keywords: learning methods, higher education, self-sufficiency development.

\section{Introduction}

At present, study programs and modules emphasise a student-directed approach and interface with the study results. In other words, it is aimed that the basic knowledge and skills which a student has to acquire during the studies would determine the content of the study program. Study results and skills are directed not only to the requirements of the program, but also to civic and employment needs. However, there are a number of study programs which are still focused on knowledge and information processing. That is, most attention is given to teaching material and academic knowledge. Although the authors of the "Tuning" project agree that it is essential to use the academic potential of the lecturer as much as possible, it should not be the determining factor in the program (Tuning, 2006). Poskiene (2011) also claims that due to technological developments and other reasons, the educational paradigm changed and became oriented at the student rather than the discipline. According to Peilakauskaite and Varanauskas (2011), a student-centred teaching implies helping students to discover their own learning styles, to understand their needs and level of motivation, and to gain effective learning skills that will be useful throughout their life. The application of this approach in practice would mean that lecturers should help students to set achievable goals; to encourage students to assess 
themselves and colleagues; to help students to work together in groups and to ensure that they use all available learning resources.

An appropriate and considerate choice of the study methods is an important condition for successful organization of the student learning process which guarantees a self-sufficient, responsible and constantly evolving personality formation (Jakube \& Juozaitis, 2012). A lecturer can contribute to the common skills' development and learner autonomy by thoroughly combining various methods. This specific approach not only makes the learning process more interesting and encourages learner participation, but is also associated with learner responsibility, self-control and motivation, skills of learning process regulation, gained experience, learning planning and creation of appropriate learning environment.

The object of the research - teaching/learning methods in higher education.

The purpose of this research - determine basic teaching/learning methods which are important for students ${ }^{6}$ common abilities and their self-sufficiency development. The research was done while applying several methods - the analysis of literature and documents and a written formquestionnaire. Quantitative data was analysed while applying MS Excel and SPSS (Statistical Package for Social Sciences) 22.0 version. During statistical analysis the methods of descriptive statistics, non-parametrictests (Mann-Whitney, Friedman, Kruskal-Wallis, chi-square) were applied.

\section{Teaching/learning methods in higher education}

Tereseviciene et al., (2011) mark that there is a link between the study methods and common skills. However, as Buividiene (2006) observes, in Lithuania, the majority of educational institutions apply the standard general teaching methods rather than trying to experiment and optimize these methods according to learners' personality. A replacement of traditional lecture with a wider range of teaching methods is also discussed in the works of Daugviliene and Ruzevicius (2009) and Visockiene and Puskunigiene (2012), among other scholars. Figure 1 illustrates the percentage of knowledge and skills students acquire during the different types of lectures.

As shown in Figure 1, knowledge is mostly acquired when students are active: they debate, teach each other, analyse, etc. The diversity of teaching methods and the change in the teaching paradigm which emphasises a studentdirected teaching and holistic approach altered the understanding of the role of the teaching/ learning methods as mediators between lecturers and students (Cvilikaite, 2013). A method is seen not only as a means to master the material of the discipline or to enhance language skills, but also as a complex tool which allows the student to adapt to teaching material, to socialize in a group, to know and evaluate oneself and to develop argumentative and critical thinking (Poskiene, 2011). According to Bulajeva, Cepiene, Lapiene et al., (2011), a 
lecture is seen as a "cheap" method, because one lecturer can convey a large amount of information during a short period of time for a large audience of people. Moreover, the method can easily be adapted to a specific audience, the taught material, time or equipment of the room (Cvilikaite, 2013). However, the information is not remembered for a long time and the method is not effective to gain knowledge which could be used in practical activities. These researchers suggest a number of other more efficient methods which could be used to develop the necessary skills. For example, group discussions promote analytical thinking, teach how to make and evaluate decisions, to alter viewpoint and socialize, enhance self-confidence and develop new ideas. Role plays when each student is assigned a particular role allow the learners to receive constructive criticism and advice. The learners are able to understand the motives and perspectives of other participants, to generalize and develop their arguments. Other methods distinguished are case study analyses which help to exchange ideas about the possible problem solutions of a particular situation; games which encourage the learners to actively participate, to solve the problems more efficiently, to understand interpersonal relations, to develop cooperation, and to promote motivation; seminars which teach to develop argumentative skills and to prepare effective presentations; brainstorming which makes each learner to feel included into and contributing to the learning process and allows to raise new ideas about the topic discussed as well as stimulates creative thinking; learning contracts which contribute to learning productivity, increase students' accuracy, working skills, attendance and social behaviour.

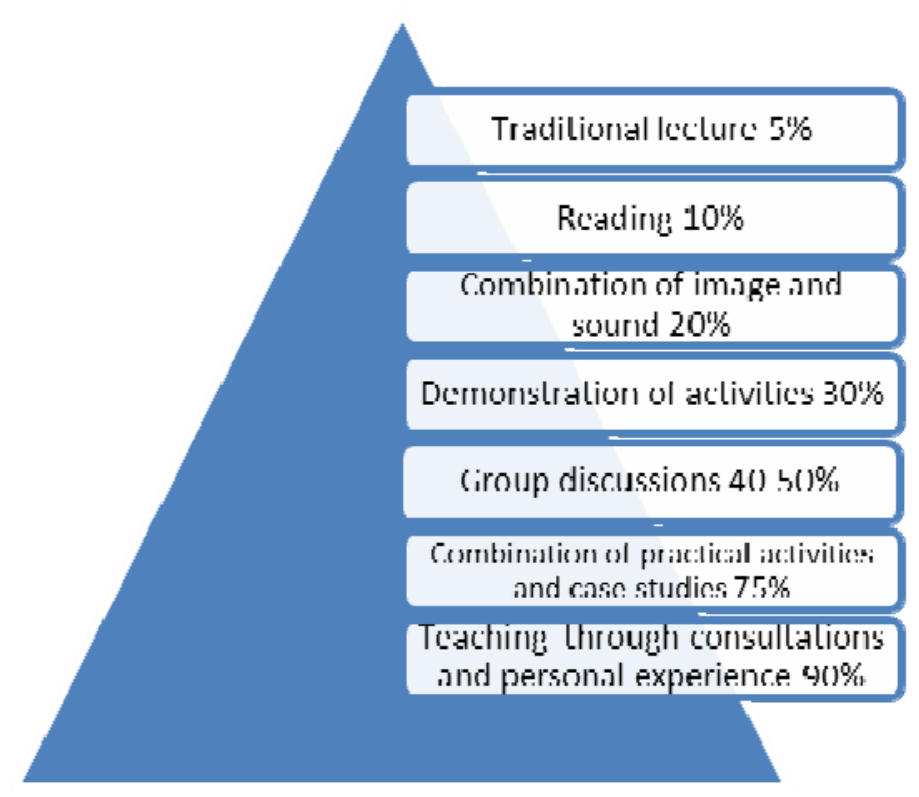

Figure 1. Knowledge and skill acquisition (Daugviliene \& Ruzevicius, 2009; Visockiene \& Puskunigiene, 2012) 
With respect to the quality of studies and the desire to develop students' ability to act independently, it is important to pay attention to the results of the studies and the internal learning processes, which affect, constitute and form approach to learning. According to Ciburiene (2012), a student achieves better results if a lecturer clarifies the benefits of the studied course by clearly formulating the aim of the discipline and by showing the practical application of the gained knowledge and skills in real-life situations and professional activities. Ciburiene (2012) emphasises that a lecturer should apply methods which promote interest in the discipline such as allowing the students to present their opinions on the topic and participate in discussions. Teaching methods (word, image and practical activities) distinguished by Rajeckas (1997) (in Ciburiene 2012) are more directed at knowledge development and retention. Siauciukeniene and Stankeviciene (2005) present a more complex classification which includes three directions of teaching: informational, operative and creative methods. As a result of the analysis of different methods applied during the study process and on the basis of Jeciuviene's (2008) methodological guidelines, the methods are divided into three major groups according to their purpose and use: a) productive technology; b) cooperation technology; c) sparing technology. Productive technology category encompasses the following methods: explanation, instruction, demonstration, work with a textbook, lecture, exercises, and testing. Cooperation technology includes conversation, discussions, cognitive games, programming, problem-based learning, case studies, and practical training. Sparing technology consists of narration, the use of audio and video material, and observation. Jeciuviene (2008) notes that productive technology is most effort demanding for the learners who have to analyse the material independently and to defend the facts and numbers argumentatively by using old and acquired knowledge. However, having in mind the development of common skills, enhancement of personal motivation and basic attitudes during the study process as well as constructing new experience, the methods of cooperation and sparing technologies are more relevant as they promote the construction of new experience and knowledge.

\section{The organization, procedures, sample and results of quantitative research}

Quantitative research was started in 2013. The students of the first and second level of humanitarian, social, physical, biomedical, technological and art studies were investigated. The questionnaires were distributed among the students of three universities at a random and personal choice, and soon afterwards the questionnaires were returned to the researchers. The questionnaire design was based on the articles which were prepared by various authors (Tandzegolskiene, Pileckaite, 2010; Tandzegolskiene, Rutkiene, Pileckaite, 2010; Stasiunaitiene, Tandzegolskiene, Rutkiene, 2012; Rutkiene, Tandzegolskiene, 2012, 2013), on the basis of I. Cvilikaite (2013) Master's 
thesis, M. Tereseviciene's and etc. (2012), and the analysis of research data and insights of qualitative research. The received meanings of separate blocks Cronbach alpha fluctuate from 0,752 to 0,905 demonstrating that the inner level of instrument's compatibility is high, and that the instrument is appropriate for the application.

The results were counted having analysed 824 respondents $^{6}$ answers. The greatest number of respondents were from Vytautas Magnus University (VMU) - 49\% (or 404 respondents), 27,7\% - from MykolasRomeris University (MRU, 228 respondents) and 23,3\% from Vilnius Gediminas Technical University (VGTU, 192 respondents). The biggest amount of students were from Bachelor's level (632, or 76,6\%), the rest - from Master's level. Most respondents were females $(59,7 \%$, or 492 respondents). It is evident that most respondents in VGTU, who are students of technological sciences in Master's programmes were males, whereas in other universities in Bachelor's level programmes of humanitarian and social sciences prevailed female students.

Study process is full of various activities which enhance the common skills of students. The majority of studying time is spent in classes. When asked whether the methods applied by the lecturers affect the development of common skills, most students responded positively: yes $-68,2 \%$, partly $-29,4 \%$.

Unfortunately, more than half of the interviewed students think that present day university lecturers mostly focus on theory $(58,7 \%)$. A third of students think that lecturers equally focus on both theory and practice $(33,8 \%)$.

In agreement with the theoretical considerations, it can be claimed that in the stages of study and course programme preparation or study process organization, the paradigm of knowledge and understanding prevails. The application of chi square allowed detecting statistically significant differences in the distribution of student opinion according to study fields: $p=0,000$ $\left(\chi^{2}=122,718, \mathrm{df}=15\right)$. Students think that lecturers in art studies are more practice-oriented, whereas lecturers in social science studies are least practiceoriented.

Different goals are posed for the undergraduate and graduate studies. Typically, in graduate studies, more attention is given to research and theoretical knowledge. However, the results of the current research do not confirm this: undergraduate students indicate more often that their studies are theory-focused, whereas graduate students mark practice-orientation. The differences between the undergraduate and graduate students' responses are statistically significant $\left(p=0,016, \chi^{2}=10,278, d f=3\right)$.

The aim of the questionnaire was to find out the most common methods used by the lecturers. It is observed that the most common teaching methods are traditional lecturing $(63,1 \%)$, testing $(35,9 \%)$, narration $(35,9 \%)$ and exercises (30,8\%). Figure 2 shows students' opinion about the most common teaching methods. The results show that the most common teaching methods (lecturing, 
explanation, narration, demonstration) are not active. Active, application and practice oriented teaching methods are relatively rare.

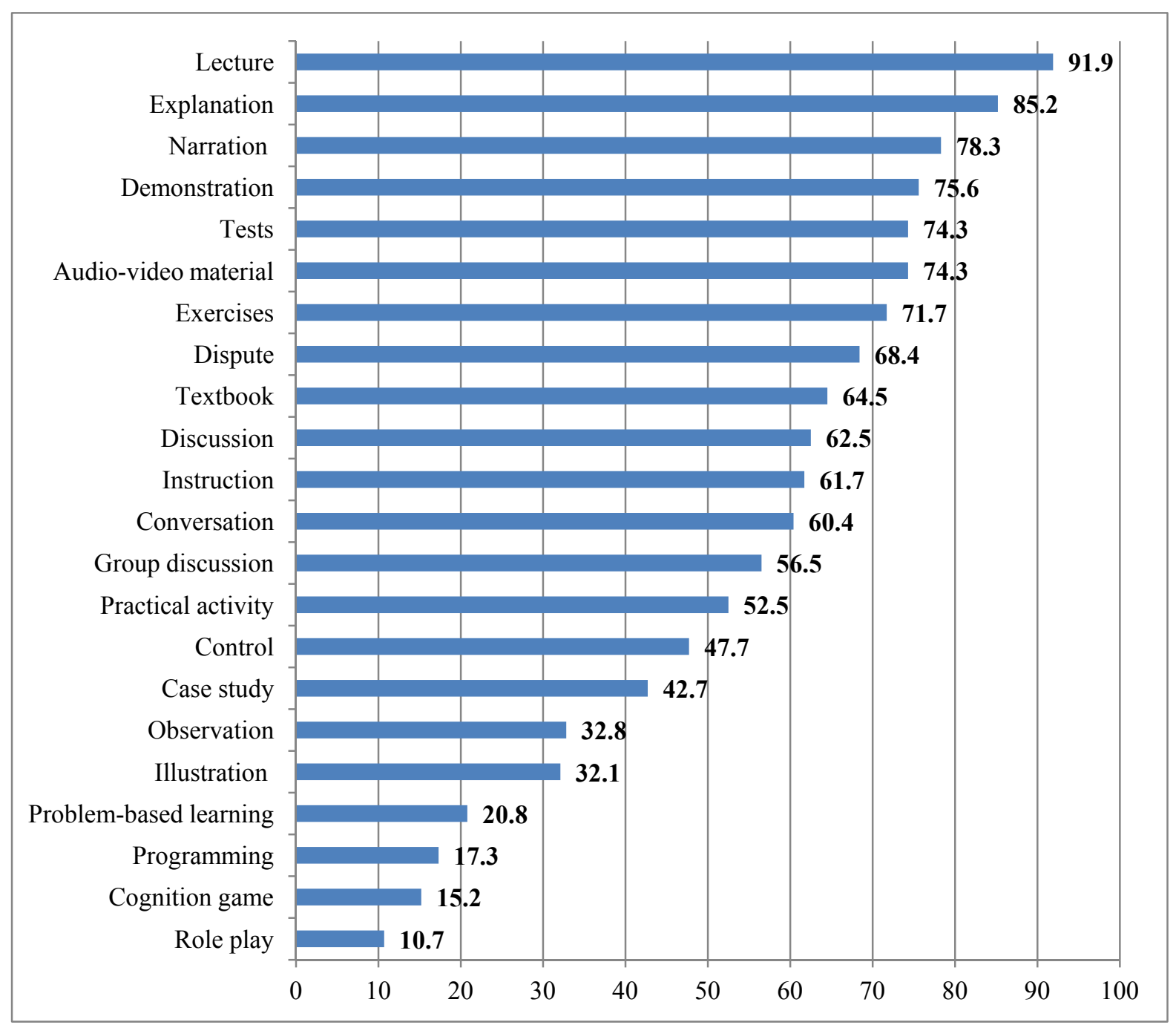

Figure 2. The most common teaching methods during the studies (\%)

A comparison of student responses has revealed that the frequency of application of specific methods significantly varies across different study fields (the differences are statistically significant $p<0,05$ ). For example, students of art claim that traditional lecturing is rare in their studies. In contrast, this method is the most frequent in the programs of technical sciences. Narration is the most common in the studies of art and social sciences; group discussion is typical to social science studies, but is rarely mentioned by the students of physical and technical sciences.

The calculation of the three indexes of the strategies applied at university studies according to technologies (productive, cooperation and sparing) reveals that productive technology exhibits the highest average index $(3,91)$, followed by sparing technology $(3,19)$ in the second place. Cooperation technology has the lowest average index $(3,16)$. After the evaluation of the data according to 
Friedman's criterion and the comparison of the application of the discussed technologies, statistically significant differences were revealed $(p=0,000)$, as presented in Table 1The analysis of undergraduate and graduates students' opinion on the differences of applied technologies has revealed that in undergraduate and graduate studies, productive technology is the most common. The least common in undergraduate studies is cooperation technology, whereas in graduate studies, sparing technology is rare. The comparison of technologies in different study cycles shows that statistically significant differences appear only when the application of sparing technology is evaluated (Mann-Whitney U test results: productive technology $-U=42680, Z=-0,704, p=0,418$; cooperation technology $-U=37856, \quad Z=-1,258, \quad p=0,208 ; \quad$ sparing technology $-U=30880, Z=-5,421, p=0,000)$.

When discussing the quality of studies, students responded that everything is important. However, regular motivation maintenance was distinguished as an especially significant factor $(29,2 \%) .12,8 \%$ of students marked a clearly structured study process to be of great value.

Table 1. Application of technologies in different study fields

\begin{tabular}{|l|l|l|l|l|}
\hline Study field & $\begin{array}{l}\text { Productive } \\
\text { technologies }\end{array}$ & $\begin{array}{l}\text { Cooperation } \\
\text { technologies }\end{array}$ & $\begin{array}{l}\text { Sparing } \\
\text { technologies }\end{array}$ & $\begin{array}{l}\text { Friedman's } \\
\text { p value }\end{array}$ \\
\hline Humanities & 3,993 & 3,221 & 3,381 & $\mathbf{0 , 0 0 0}$ \\
\hline Social sciences & 3,966 & 3,328 & 3,577 & $\mathbf{0 , 0 0 0}$ \\
\hline $\begin{array}{l}\text { Physical } \\
\text { sciences }\end{array}$ & 3,813 & 3,059 & 3,056 & $\mathbf{0 , 0 0 0}$ \\
\hline $\begin{array}{l}\text { Biomedical } \\
\text { sciences }\end{array}$ & 3,729 & 2,704 & 2,800 & $\mathbf{0 , 0 0 0}$ \\
\hline $\begin{array}{l}\text { Technical } \\
\text { sciences }\end{array}$ & 3,882 & 3,059 & 2,903 & $\mathbf{0 , 0 0 0}$ \\
\hline Arts & 3,750 & 2,956 & 3,556 & $\mathbf{0 , 0 0 0}$ \\
\hline $\begin{array}{l}\text { Kruskal- } \\
\text { Wallis' } \\
\text { value }\end{array}$ & $\mathbf{0 , 0 0 3}$ & $\mathbf{0 , 0 0 0}$ & $\mathbf{0 , 0 0 0}$ & \\
\hline
\end{tabular}

Having in mind the emphasis on the development of common and special skills, the enhancement of practice-oriented skills, the change of the teaching paradigm into the learning one, teaching methods acquire an especially significant role in the study process. As is seen (Figure 3), these are the methods of productive and cooperation technologies. 


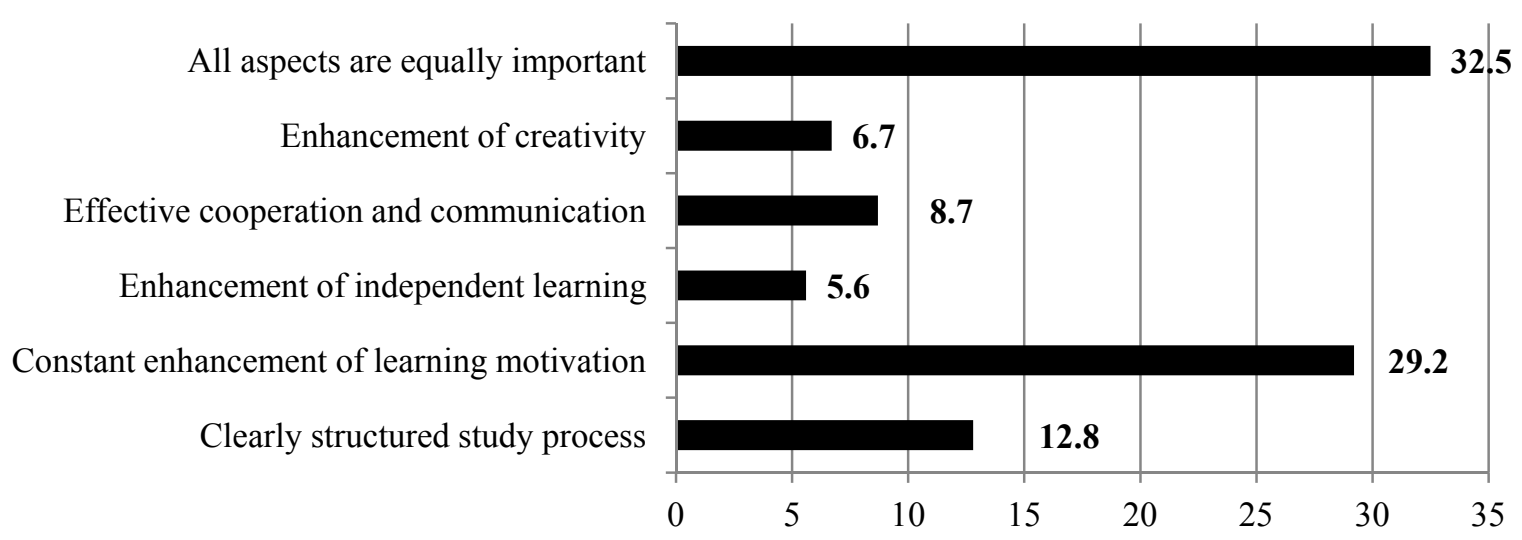

Figure 3. Aspects which are important to study quality

In the opinion of the students, active teaching methods are applied rather seldom in the study process: once a week $(27,8 \%)$, once a month $(23,2 \%)$, or, occasionally, several times a week $(21,1 \%)$. It should be noted that even $2,6 \%$ of students do not recognize active teaching methods or have not experienced them

To summarize the results of the conducted research it can be claimed that students understand learning as the acquisition of knowledge and skills, the processing of information and the inner growth of the individual. With respect to the self-sufficient learning it turned out that students mostly see the value in the possibility to plan their study process, to observe, adjust and evaluate their learning results and process. In the opinion of the students, independency in the study process is seen in the possibilities to find different solutions in new learning situations (the combination of existing and new knowledge). Students are mostly encouraged to act independently by self-control, motivation and responsibility. Lecturers, in the opinion of the students, should give more freedom and responsibilities in decision making process, to allow the students to give their opinions and to apply different teaching methods.

\section{Conclusions}

"Learning" is a very broad concept, which means the ability to learn by considering the learning stages and evaluation processes as well as the replacement of traditional teaching methods by the active ones during the university studies. The concept also encompasses a motivated student's selfregulation of the learning process, directed to life-long learning. The analysis of the novel and topical teaching methods for the study process has shown that the methods of productive technologies which include explanation, instruction, demonstration, work with textbook, lecture, exercises and testing are the most common. An especially popular method is lecturing. The mentioned methods are valid for the development of the common skills and enhancement of selfsufficiency during the study process as they are related with information acquisition and processing. However, when it comes to the active planning of 
the student's learning process, the issue of responsibility in the achievement of the set goals, motivation development, cooperation, problem identification and inter-disciplinarity, the mentioned methods do not transfer the idea of the selfsufficient learning or common skills. In order to promote the common skills, to develop personal motivation and underlying attitudes as well as construct new experience, the methods of cooperation and sparing technologies are mostly suitable as they invite the construction of new experience and knowledge.

\section{References}

Buivydiene, R. (2006). Mokymo metodu optimizavimas destant profesijos dalykus. Downloaded from http://jaunasis-mokslininkas.asu.lt/smk_2006/pedagogika/ Buivydiene\%20Regina.pdf(active: 2015-02-20).

Bulajeva, T.,Cepiene, A., Lapiene, D. et al. (2011).Studijuprogramu atnaujinimas: kompetencijupletotes ir studiju siekiniu vertinimo metodika. Downloaded from: http://www4066.vu.lt/Files/File/STUDIJU\%20PROGRAMU\%20ATNAUJINIMAS\%2 0KOMPETENCIJU\%20PLETOTES\%20IR\%20STUDIJU\%20SIEKINIU\%20VERTIN IMO\%20METODIKA_sujungta.pdf(active: 201302 25).

Cvilikaite, I. (2013). Isidarbinamumui reikalingubendrujugebejimupletojimasstudiju proceso metu: studentupoziuris. Masterthesis. Kaunas: Vytauto Didziojo universitetas.

Ciburiene, J. (2012). Mokymo(si) metodu ir stiliaus dermeaukstojoje mokykloje. Studijos siuolaikinejevisuomeneje. Mokslo darbai, Siauliai: VsISiaures Lietuvos kolegija, 3 (1), $38-45$.

Daugviliene, D.,Ruzevicius, J. (2009). Studiju kokybe Bolonijos proceso kontekste. Downloaded from: http://ttvam.lt.gvazdikas.serveriai.lt/uploads/documents/leidiniai versl_teis_akt_t1/1198.pdf (active: 2014-03-18).

Jakube, A., Juozaitis, A. (2012). Bendrujukompetenciju ugdymas aukstojoje mokykloje. Vilnius: Vilniaus universitetas.

Jeciuviene, M. (2008). Studentu mokymo kokybes veiksniai. Organizaciju vadyba: sisteminiai tyrimai, Kaunas: Vytauto Didziojo universitetas, 45, 44-45.

Peilakauskaite, K., Varanauskas, A. (2011). Studiju programu atnaujinimas: studentu vaidmuo diegiant ir tobulinant kompetencijomis grista ir istudenta orientuotastudiju sistema. Vilnius: Kriventa.

Poskiene, A. (2011). Nauja paradigma - seni metodai ar sena paradigma - nauji metodai? Downloaded from: http://www.kalbos.lt/zurnalai/18_numeris/21.pdf(active: 2015-0220).

Rutkiene, A.,Tandzegolskiene, I. (2012). Manifestation of Students' Independent Activity During University Studies in Social Sciences. LICE-2012: London International Conference on Education (LICE-2012), London, UK: Proceedings. London: Infonomics Society, $113-115$.

Rutkiene, A.,Tandzegolskiene, I. (2013). Students' Ability to ActIndependentlyin University Studies. Journal of International Scientific Publications: Educational Alternatives, 11 (1), 190-205. Bulgaria: InfoInvest Ltd. Downloaded from: http://www.scientificpublications.net/download/educational-alternatives-2013-1.pdf (active: 2015-02-20).

Siauciukeniene, L., Stankeviciene, N.(2005). Bendrosios didaktikos pagrindai. Kaunas: Technologija.

Tandzegolskiene, I., Pileckaite, R. (2010). Socialiniu mokslu srities studentusavarankiskos veiklos raiskauniversitetinese studijose. Pedagogika, Vilnius: Vilniaus pedagoginis universitetas, 97, 43-49. 
Tandzegolskiene, I., Rutkiene, A., Pileckaite, R. (2010). Savarankiskos veiklos samprata universitetinese studijose. Profesinis rengimas: tyrimai ir realijos $=$ Vocational Education: Researchand Reality, Kaunas: Vytauto Didziojo universitetas, 19, 196-209.

Tereseviciene, M., Bulajeva, T., Cepiene, A. et al. (2011). Studiju programu atnaujinimas: kompetencijupletotes ir studiju siekiniu vertinimo metodika. Vilnius: Vilniaus universitetas

Tereseviciene, M., Kaminskiene, L.,Zydziunaite, V.,Gedviliene, G. (2012). Savimoka ir savarankiskas mokymasis aukstojoje mokykloje: kritine diskusijos analize. Acta Pedagogika Vilnencia. Vilnius: Vilniaus universitetas, 29, 47-60.

Tuning. Europos svietimo strukturu suderinimas. Downloaded from: http://www.unideusto. org/ tuningeu/images/stories/documents/Lithuanian_version.pdf (active: 2015-02-20).

Visockiene, O.; Puskunigiene, A. (2012). Siuolaikiniai mokymosi metodai. Kaunas: Technologija. 